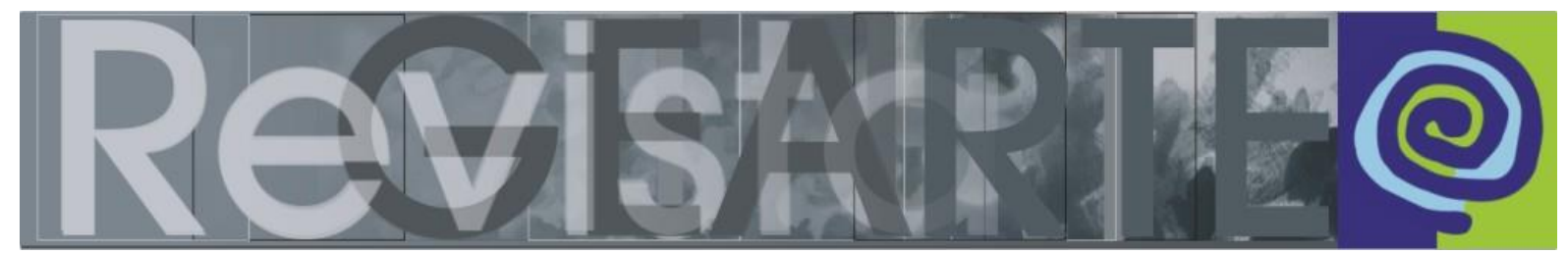

ISSN 2357-9854 | e-ISSN 2596-3198 (online)

\title{
Arte(sania) na escola: (desa)fios da arte nos anos iniciais do Ensino Fundamental
}

\author{
Fernanda Maria Santos Albuquerque \\ (Universidade Federal de Pernambuco - UFPE, Caruaru/PE, Brasil) \\ Conceição Gislâne Nóbrega Lima de Salles \\ (Universidade Federal de Pernambuco - UFPE, Caruaru/PE, Brasil) \\ Nádia Priscila de Lima Carvalho \\ (Universidade Federal de Pernambuco - UFPE, Caruaru/PE, Brasil)
}

\begin{abstract}
RESUMO - Arte(sania) na escola: (desa)fios da arte nos anos iniciais do Ensino Fundamental - Aborda os desafios da arte nos anos iniciais do Ensino Fundamental e os seus fios de resistência emaranhados à experiência e à infância na escola. Reflete acerca da minoração da experiência, sobretudo no campo da educação, a partir do projeto da modernidade e destaca as suas consequências na escola, especificamente, na arte e no seu ensino nos anos iniciais do Ensino Fundamental. A partir de uma pesquisa cartográfica, trata dos (desa)fios da arte nos anos iniciais do Ensino Fundamental, evidenciando a artesania como fio de passagem da arte na escola, transformando-a em espaçotempo para a arte, a experiência e a infância, para a aprendizagem, a vida e o mundo.
\end{abstract}

PALAVRAS-CHAVE

Arte. Anos iniciais do Ensino Fundamental. Artesania. Escola.

ABSTRACT - Craftsmanship at school: challenges of the art in the early years of elementary school - It addresses the challenges of art in the early years of elementary school and its tangled thread resistance to experience and childhood in school. It reflects on the lessening of experience, especially in the field of education, from the project of modernity and highlights its consequences in school, specifically, in art and in its teaching in the early years of Elementary Education. Based on a cartographic research, it deals with challenges of the art in the early years of elementary school, showing craftsmanship as a tangled thread for the passage of art at school, transforming it into a spacetime for art, experience and childhood, for learning, life and the world.

KEYWORDS

Art. Early years of elementary school. Craftsmanship. School.

RESUMEN - Arte (sania) en la escuela: (desa)fíos del arte en los primeros años de la escuela primaria - Aborda los desafíos del arte en los primeros años de la escuela primaria y los hilos de resistencia enredados a la experiencia y la infancia en la escuela. Reflexiona sobre el debilitamiento de la experiencia, especialmente en el campo de la educación, desde el proyecto de modernidad y destaca sus consecuencias en la escuela, específicamente, en el arte y en su enseñanza en los primeros años de Educación Primaria. A partir de una investigación cartográfica, aborda los (des) hilos del arte en los primeros años de la escuela primaria, destacando la artesanía como hilo conductor del paso del arte en la escuela, transformándola en un espacio-tiempo para el arte, la experiencia y la infancia, para aprendizaje, vida y mundo.

PALABRAS CLAVE

Arte. Primeros años de la escuela primaria. Artesanía. Escuela.

ALBUQUERQUE, Fernanda Maria Santos; SALLES, Conceição Gislâne Nóbrega Lima de; CARVALHO, Nádia 


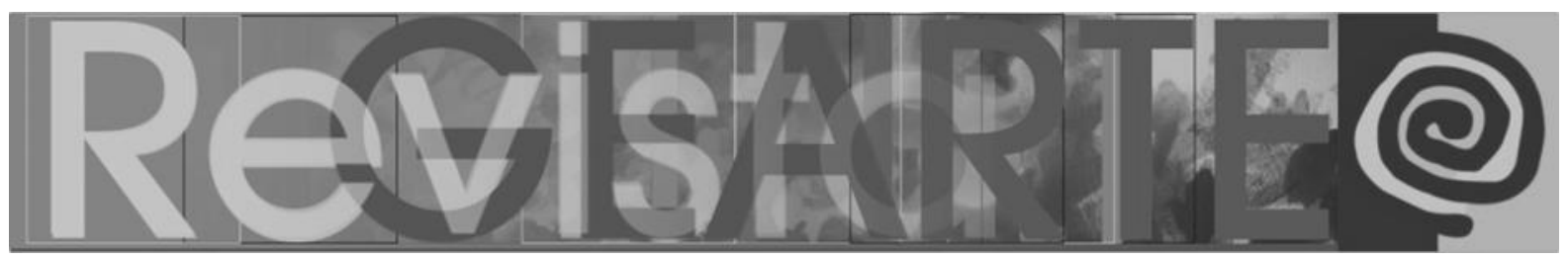

\section{Questões iniciais}

O que importa escrever agora? Importa escrever agora? O que importa agora? Para pensar tais questões, evocamos as palavras de Manoel de Barros quando enuncia que "As coisas jogadas fora têm mais importância - como um homem jogado fora", afinal de contas "O que é bom para o lixo é bom para a poesia" (BARROS, 2015, p. 45).

Encontramos nas palavras manoelinas a importância da escrita poética e do "homem jogado fora", a importância de uma escrita poética acerca do "homem jogado fora". Roboramos que, ambos, escrita e homem, parecem corriqueiramente, e talvez cada vez mais, jogados fora, rechaçados pela informação e pela técnica, pela pressa de um tempo chrónos e do inevitável progresso - "essa flecha tensa que nos empurra para frente, isto é, ao pé de um despenhadeiro e então à morte" (SKLIAR, 2019, p. 111-112).

No entanto, ressaltamos que "a linguagem também pode ser uma forma de pausa que sirva para habitar um tempo profundo, que nos vincule mais com a intensidade do que com a voracidade das cronologias" (SKLIAR, 2019, p. 115). Conforme Skliar (2019), a escrita poética atravessa o corpo, faz o corpo presente, situa-o com intensidade no mundo, passa a dizê-lo, a passá-lo, a inscrevê-lo. A escrita poética recobra o corpo jogado fora, inferimos.

Sendo assim, desejamos uma escrita poética que atravesse os corpos presentes e situados intensivamente no mundo. Para tal, instalamo-nos no campo da educação, no nível da Educação Básica, na etapa dos anos iniciais do Ensino Fundamental, na escola. Os corpos ditos, passados e inscritos por esta escrita, que se pretende poética, são os nossos próprios, de pesquisadoras, os das crianças e das professoras do segundo e do terceiro ano do Ensino Fundamental, das gestoras das mesmas e das coordenadoras municipais para do primeiro ao terceiro ano do Ensino Fundamental da rede, participantes de uma pesquisa. 


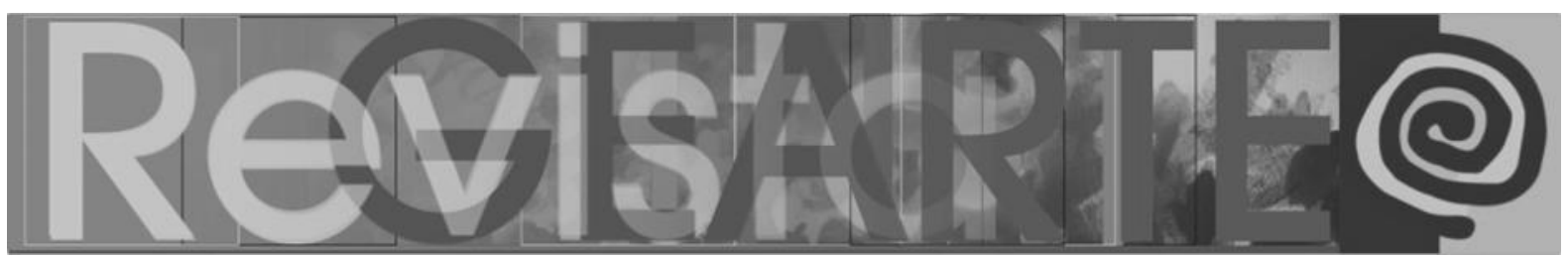

Com inspiração cartográfica (PASSOS; KASTRUP; ESCÓSSIA, 2015), considerando a subversiva transformação do metá-hodos em hodos-metá, a referida pesquisa não teve um caminho predeterminado a partir de metas, mas teve seu caminho traçado junto às suas metas, de modo que o caminho se revelou tão ou mais importante que seus imprecisos início e fim. Dessa forma, caminhamos junto às professoras e, sobretudo, às crianças e traçamos como meta de pesquisa a cartografia dos (des)encontros (im)possíveis da infância, da experiência estética e da arte na escola.

Os (des)encontros (im)possíveis cartografados desfaleceram todo saber e poder totalitários na escola. Nestes, a infância brotou, mesmo quando as condições parecem impróprias a ela, quando condiziam muito mais com a maioridade e suas predeterminações. A infância fez-se "condição da experiência" (KOHAN, 2007). Nos (des)encontros (im)possíveis cartografados, a experiência estética parecia soprar vida aos anos iniciais do Ensino Fundamental, mesmo em meio à resistência ao caráter inefável na educação escolar. Ainda em meio a estes, a arte envolvia-se com a infância e a experiência estética, resistindo aos desafios postos a ela.

Dito isto, enfatizamos que nesta escrita passam-nos e inscrevem-nos, em específico, os desafios da arte nos anos iniciais do Ensino Fundamental e os seus fios de resistência emaranhados à experiência e à infância. Dos fios de resistência, destacamos ainda a artesania, proposta de Sennett (2015a), como possibilidade de encontro e cooperação, de estar junto, e de habitar de modo intenso, com todo o corpo, o espaçotempo presente, a escola.

Assim, as primeiras palavras referem-se ao ataque do projeto da modernidade à experiência - esta que envolve a escrita e os corpos, a infância e a arte. Elas seguem abarcando as consequências da minoração da experiência na educação e, em específico, na arte e no seu ensino nos anos iniciais do Ensino Fundamental, tratando dos seus desafios. As palavras passam, então, aos fios da 


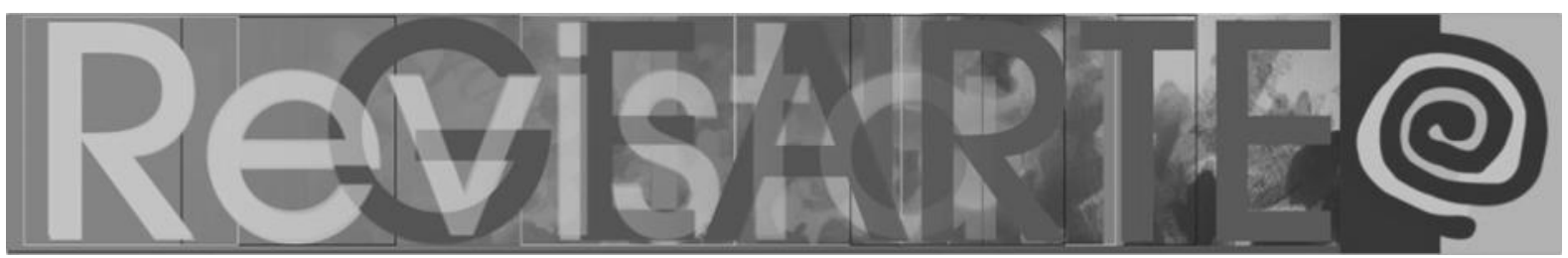

arte(sania) na escola - fios tecidos, sobretudo, pelas crianças. E assim, a escrita deixa-nos dizendo que a escola pode ser espaçotempo para crianças, professoras e pesquisadoras, para a arte, a experiência e a infância, para a aprendizagem, a vida e o mundo, para corpos e para a escrita. Desse modo, passemos às primeiras palavras, ou melhor, que elas nos passem e inscrevam-nos a seguir.

\section{$\mathrm{O}$ ataque do projeto da modernidade à experiência}

Para escrever em torno da experiência e do ataque do projeto da modernidade a ela, partimos da consideração feita por Sabino (2017) de que a experiência é comum à arte e à educação, que ela é supervalorizada, mas, por vezes, também supernaturalizada. A aliança entre arte e educação por meio da experiência produz verdades para além daquilo que parece ser dito e, por isso, Sabino (2017) a investiga, atentando ao acento pedagogizante presente nas práticas artísticas e na sua solicitação por parte da educação.

Em meio às diferentes relações entre a arte e a educação, estabelecidas através da experiência, encontradas por Sabino (2017), destacamos a possibilidade de relações que se entrelaçam com a infância. Neste sentido, inferimos que o corpo das crianças e os seus agenciamentos com o mundo podem ser afetados pelo modo como pensamos a experiência na escola, em seu diálogo com a arte e a infância. Assim, há que se considerar que "Nós somos nosso corpo. Toda educação é educação do corpo" (STRAZZACAPPA, 2001, p. 79) e que é importante explicitar o modo como pensamos a relação entre a experiência, a educação, a arte e a infância em nossa pesquisa, nesta escrita.

Neste sentido, enfatizamos que a experiência não é uma substância, a qual possamos identificar facilmente sua presença ou ausência em determinadas relações, mas sua presença se faz em diferentes tons e possibilidades. Aqui, um primeiro tom, com o qual a experiência faz-se presente, advém dos ensaios de Walter Benjamin (1987). O autor evidencia a importância da tradição, da necessidade e das principais condições de comunicação da experiência 


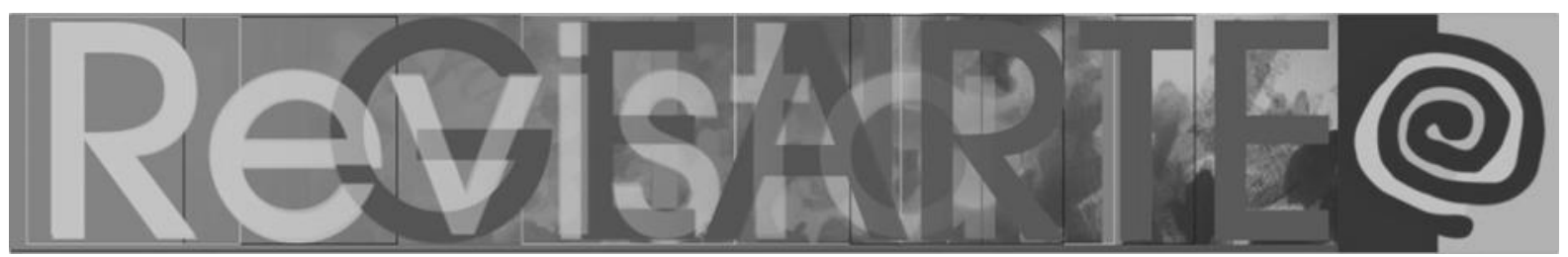

(experiências comuns, trabalho artesanal e conselhos), da valorização do saber que advém das experiências para o con-viver.

No entanto, segundo Benjamin (1987), as ações da experiência estão em baixa desde a modernidade. Uma nova forma de miséria havia surgido com o monstruoso desenvolvimento da técnica sobrepondo-se ao homem, afirmou-nos Benjamin (1987). A distância criada entre as dimensões humanas levou-nos à miséria, à pobreza extrema, à privação de experiências.

A partir de Benjamin, pudemos perceber que a modernidade parece ter tido a pretensão de instaurar espaços e tempos sem rastros, impessoais, generalizáveis, no entanto, a experiência (r)existe em nós, em nossos corpos. A experiência pode ser "o que nos passa, o que nos acontece, o que nos toca. Não o que se passa, não o que acontece, ou o que toca" (LARROSA BONDÍA, 2002, p. 21), ela afeta-nos.

Para Larrosa Bondía (2011), a experiência enfatiza a subjetividade, a formação e/ou transformação, e pode ser mais bem percebida a partir de três dimensões que the são próprias: exterioridade, alteridade e alienação que têm a ver com o acontecimento, com o que é da experiência; reflexividade, subjetividade e transformação que têm a ver com o sujeito da experiência, com o quem da experiência; e passagem e paixão que têm a ver com o movimento mesmo da experiência.

De uma integridade tal, acontecimento, sujeito e movimento requerem práticas de liberdade, livres agenciamentos entre exterioridades, reflexividade, passagem e paixão; requerem campos capazes de desterritorialização, sem domínios, sem fronteira; campos como o da educação. Larrosa Bondía (2011) propõe-nos a exploração destas possibilidades neste campo, estimulando-nos a pensar a educação através do diálogo entre a experiência e o sentido, reforçando a importância de insistir em experiências nas salas de aula, uma vez que a linguagem da educação parece estar cheia de fórmulas provenientes da economia, da gestão, 


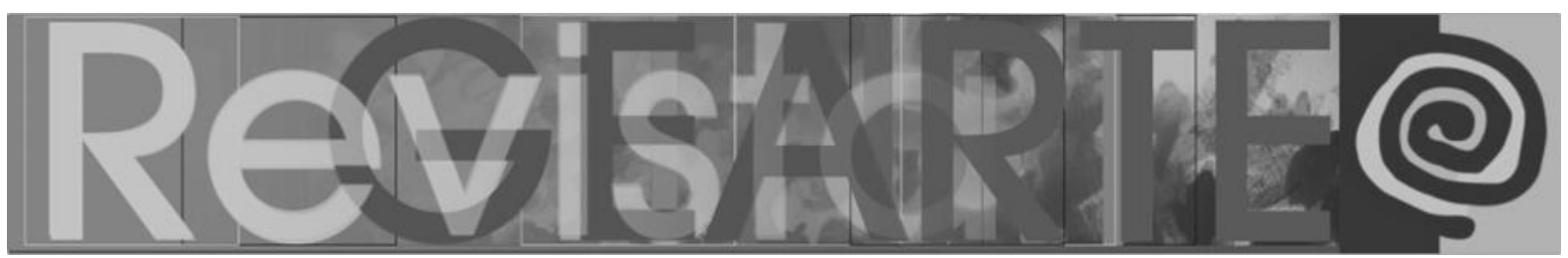

das ciências positivistas, de saberes que fazem tudo calculável, identificável, compreensível, mensurável, manipulável (LARROSA BONDÍA, 2011).

A produção, a eficiência e a eficácia, desde o empobrecimento da experiência com a modernidade, parecem mediar a nossa relação com o trabalho, com o outro e conosco, parecem mobilizar uma educação de um tipo de corpo economicamente viável. Sennett (2006) problematiza a ordem social moderna, baseada, sobretudo, na economia, e caracteriza este tipo de ser humano requerido não só nos negócios, mas, ao que tudo tem indicado, na educação.

Para Sennett (2006, p. 14), estes tipos de seres humanos nada comuns devem possuir "uma individualidade voltada para o curto prazo, preocupada com as habilidades potenciais e disposta a abrir mão das experiências passadas". Para este tipo de ser humano, Sennett (2006) coloca três desafios relacionados ao tempo de cuidar de si mesmo e da narrativa de sua própria vida, ao talento frente à cultura da meritocracia e ao descarte de experiências já vivenciadas.

Dentre os desafios ao tipo de ser humano ideal desde a modernidade, identificados por Sennett (2006), destacamos o desafio relacionado ao talento. O autor reflete acerca da voracidade do tempo e das exigências na economia moderna, afirmando que "o talento também é uma questão de cultura" (SENNETT, 2006, p. 13). O mesmo autor destaca a militância da ordem social moderna contra o ideal do artesanato, que o aponta como economicamente destrutivo (SENNETT, 2006).

Como já trazido por Benjamin (1987), o saber da experiência e o trabalho artesanal são potências do con-viver, requerem um tempo não só prolongado, mas também intenso, que vem sendo esgotados. Mudanças em nossas ações cotidianas evidenciam o empobrecimento da experiência, a disposição de força e potência dos sentidos, por exemplo, é cerceada e "quase sempre ligada ao consumo" (RODRIGUES; ROBLE, 2015, p. 205). Nossos atos de conversar, de morar, de caminhar e de trabalhar também não parecem dotados das potências do con-viver advindas da experiência. Conforme reflete Duarte Júnior (2000, p. 20):

ALBUQUERQUE, Fernanda Maria Santos; SALLES, Conceição Gislâne Nóbrega Lima de; CARVALHO, Nádia 98 Priscila de Lima. Arte(sania) na escola: (desa)fios da arte nos anos iniciais do Ensino Fundamental Revista GEARTE, Porto Alegre, v. 8, n. 1, p. 93-117, jan./abr. 2021.

Disponível em: http://seer.ufrgs.br/gearte 


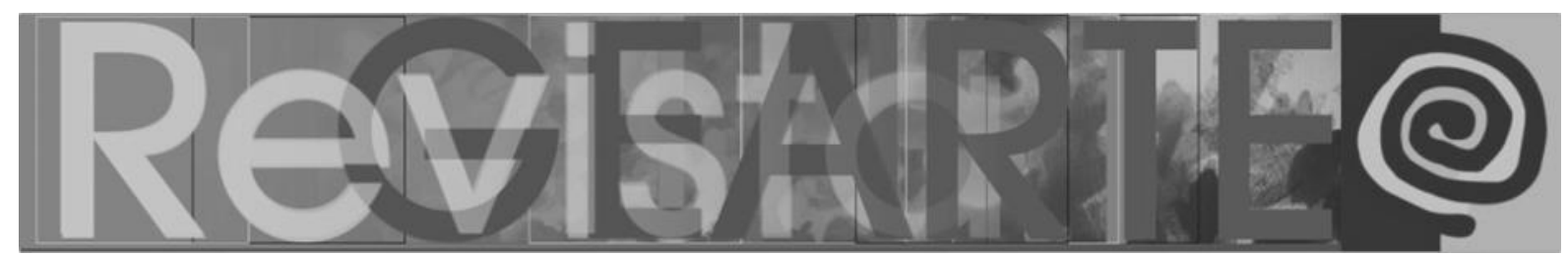

Nossas casas não expressam mais afeto e aconchego, temerosa e apressadamente nossos passos cruzam os perigosos espaços de cidades poluídas, nossas conversas são estritamente profissionais e, na maioria das vezes, mediadas por equipamentos eletrônicos, nossa alimentação, feita às pressas e de modo automático, entope-nos de alimentos insossos, contaminados e modificados industrialmente, nossas mãos já não manipulam elementos da natureza, espigões de concreto ocultam horizontes, os odores que comumente sentimos provêm de canos de descarga automotivos, chaminés de fábricas e depósitos de lixo, e, em meio a isso tudo, trabalhamos de maneira mecânica e desprazerosa até o estresse.

Com isso, não negamos que a modernidade proporcionou novos saberes, tecnologias e melhorias para a con-vivência. No entanto, como ressalta Sennett (2006), as mudanças da ordem social moderna, pautadas sobretudo no trabalho, no talento e no consumo, não libertaram as pessoas. Sennett (2015a, 2015b) propõe a retomada necessária à vida cotidiana da artesania e da cooperação.

A artesania reflete um processo de criação a partir de outra perspectiva, envolvendo o artífice, de corpo inteiro, e os materiais com que trabalha de modo mais significativo e prolongado (SENNETT, 2015a). O tempo é requerido na artesania, como o é também na cooperação (SENNETT, 2015b), e ambas, através da experiência, são importantes na escola.

É na tentativa de forjar práticas de liberdade, de alçar uma relação com o mundo e com o outro para além da utilidade e da competitividade, alçar modos intensos de viver que retomamos Duarte Júnior (2000), quando evidencia o ensino de arte como um precioso instrumento para uma educação que nos leva não apenas a descobrir formas até então inusitadas de sentir e perceber o mundo, como também desenvolvendo e acurando os nossos sentimentos e percepções acerca da realidade vivida.

Os estudos de Duarte Júnior potencializam a possibilidade de pensarmos a educação advinda também da experiência, tendo o ensino de arte como via, no entanto, não pudemos ignorar a caracterização dessa arte como uma "arte adulta", que não regressa ao "infantil" (DUARTE JÚNIOR, 2000, p. 154). Neste momento, 


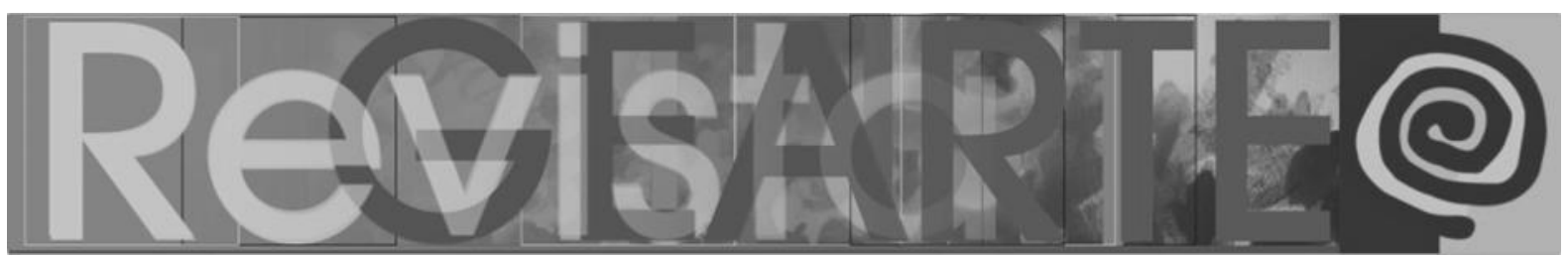

afastamo-nos de Duarte Júnior e recorremos a Olarieta (2013) para assumirmos um outro significado do adjetivo "infantil", afastando-o da ingenuidade, da imaturidade e da não seriedade comumente atribuídas ao mesmo. Concordamos com Olarieta quando ela traz que o infantil:

\begin{abstract}
[...] é um verbo, uma ação, um exercício que abre mundos, que traz novas formas de olhar e de transformar o que achamos já conhecido, já sabido; é olhar o mundo como se fosse a primeira vez; é trazer sua novidade, sua abertura - essa que tentamos de forma infrutífera cristalizar com nossa linguagem que explica e nos fornece certezas que fecham; é entrar no movimento do mundo que nada tem a ver com essa monótona repetição mecânica do mesmo que nossos orgulhosos relógios quantificam e secam (OLARIETA, 2013, p. 19).
\end{abstract}

Insistimos que a infância, junto à arte na escola, recobra experiência. Infância, arte e experiência (re)fazem-nos continuamente, fazem-nos diferentes dos sujeitos preconizados pelo iluminismo. Em meio a estas, são forçadas fissuras potentes, instituintes, libertárias e criadoras em agregação, fissuras que modificam as formas de existência. Neste sentido, as palavras passam-nos novamente, desta vez, para nos inscrever junto aos (dessa)fios da arte nos anos iniciais do Ensino Fundamental.

\title{
Desafios da arte nos anos iniciais do Ensino Fundamental
}

A arte pode ser um caminho a outras regiões, a outros territórios, à alteridade, ao encontro com outras existências que acarretam nossa subjetividade, nosso modo de ser e estar no mundo. Não obstante, reconhecemos que, por vezes, as experiências estéticas com a arte na educação escolar esbarram em situações tão somente técnicas, em padrões de existência, na supremacia da racionalidade em relação às sensibilidades.

Assim, entre fios e desafios, refletimos sobre a relação entre infância e arte no contexto dos anos iniciais do Ensino Fundamental a partir, sobretudo, de um "dizer infantil", desde as próprias experiências (estéticas) das crianças. Junto às professoras e às crianças (ambas identificadas por nomes fictícios), às coisas e aos espaçostempos da escola, caminhamos traçando - traçamos caminhando - o

ALBUQUERQUE, Fernanda Maria Santos; SALLES, Conceição Gislâne Nóbrega Lima de; CARVALHO, Nádia 100 Priscila de Lima. Arte(sania) na escola: (desa)fios da arte nos anos iniciais do Ensino Fundamental.

Revista GEARTE, Porto Alegre, v. 8, n. 1, p. 93-117, jan./abr. 2021.

Disponível em: http://seer.ufrgs.br/gearte 


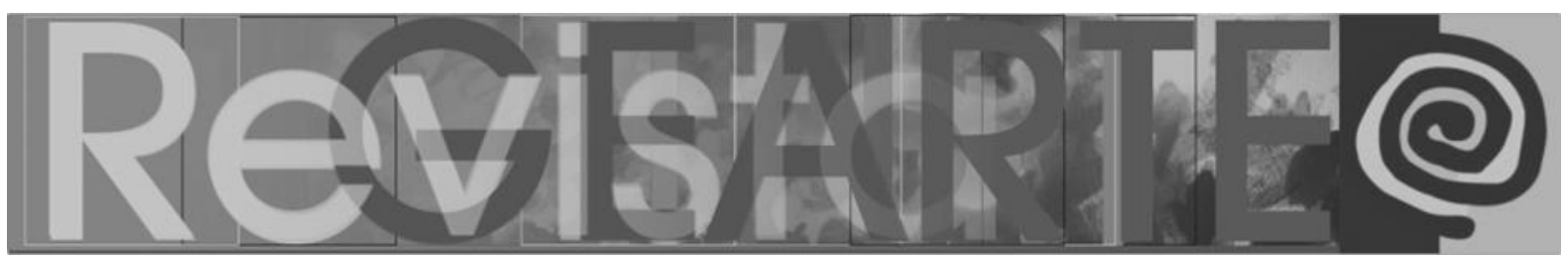

nosso plano comum e heterogêneo de produção de dados, partilhando os acontecimentos, os processos de subjetivações e os movimentos em torno da experiência, da infância e da arte na escola.

As partilhas na escola aconteceram através da observação participante, do diário de campo, de correspondências acerca da presença da arte, da infância e da experiência nos anos iniciais do Ensino Fundamental, da construção de mapas que indicavam onde e quando podíamos encontrar estas no espaçotempo escolar, de uma instalação a partir desses mapas e, sobretudo, através de conversas.

As conversas, tal como colocado por Ferraço e Alves (2018), constituem uma forte estratégia para uma aproximação mais espontânea com as pessoas, possuem a força dos encontros, dos afetos, das amizades. Segundo os autores,

[...] quando nos envolvemos em conversas tecidas por relações de afetoamizades, quando nos predispomos a entrar em uma rede de conversações em nossas pesquisas, buscando potencializar encontros com os praticantes dos cotidianos das escolas, nunca saberemos aonde as conversas poderão nos levar e, para nós, aí reside o mistério e a magia das práticas da conversa: nos deixar levar pelas redes e pelas diferenças que atestam a permanente novidade da vida (FERRAÇO; ALVES, 2018, p. 62-63).

Assim, a partir de nossas partilhas (regadas a muita conversa), fomos levadas, a princípio, a alguns desafios da arte. Um destes desafios é a descaracterização da arte como componente curricular preconizado pela legislação educacional no Brasil. Esta área específica do conhecimento é, comumente, caracterizada como um elemento extracurricular nos anos iniciais do Ensino Fundamental. Como a gestora Rosa reconhece em uma de nossas conversas:

[...] tem sempre o conteúdo, que é a base, e tem o extra. E você sabe que a gente se preocupa mais com a base que com o extra, que a gente, mesmo sendo professores, nós temos o olhar fixo ainda no conteúdo que vai para a prova. Todos nós, professores, temos isso! [...] nós ainda não concebemos que uma atividade extra é tão importante quanto conteúdo por escrito, trabalhado na prova, porque é aprendizado pra vida! (Informação verbal) $)^{1}$ 


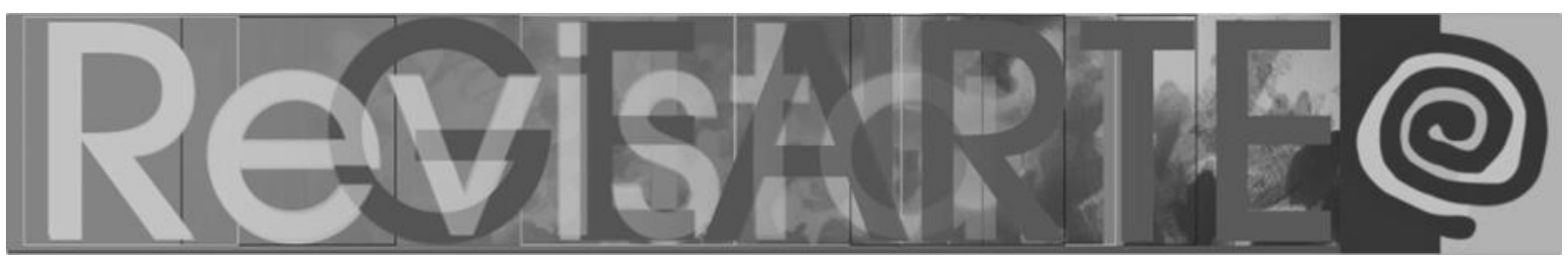

As cisões modernas desembocam no currículo. A dicotomia criada entre a base e o extra no currículo parece invizibilizar os rastros da arte na escola, homogeneizando conhecimentos e experiências, tornando-os impessoais, tal qual colocado por Benjamim (1987). A arte e os demais componentes curriculares parecem perder suas especificidades e serem classificados, redefinidos e homogeneizados como de maior ou menor peso.

A arte é classificada como de menor peso e, junto a ela, parecem estar outras áreas específicas do conhecimento, como a educação física e o ensino religioso. Estes três componentes curriculares dos anos iniciais do Ensino Fundamental, não raras vezes, partilham as aulas dos últimos dias da semana, as metodologias e os instrumentos de avaliação, ou mesmo a ausência de tudo isso.

Consideramos que a ausência de tudo isso, disto tudo que, como a professora Rosa explicitou, ainda é considerado extracurricular, pode estar implicando o pouco de arte, experiência e infância na escola. E destacamos que, muito embora a professora Rosa reconheça a importância de que a escola ensine para a vida, considerando inclusive a arte, a classificação dicotômica e homogênea dos conhecimentos parece prevalecer. $O$ desejo da professora Rosa de um aprendizado escolar para a vida parece estar sendo soterrado pelo peso de outros aprendizados.

Conversando agora com as coordenadoras pedagógicas do primeiro ao terceiro ano do Ensino Fundamental do município, o impasse entre os componentes curriculares é acentuado. A respeito da arte, a coordenadora Violeta reconhece: "Mas é verdade! É a pura realidade! É dito que é uma matéria que não é de peso, feito matemática e português, mas que é tão importante, né?' (Informação verbal) ${ }^{2}$, e acrescenta:

- [...] essa questão de arte [...], não é uma coisa que o professor tem toda semana na sua aula, não é uma coisa que ele planeja pra toda a semana na sua aula, não é uma coisa que ele planeja pra toda a semana na sua aula, se trabalha mais a língua portuguesa, a matemática... tem a nota, tem tudo, mas a gente vê em alguns casos disso aqui, que eles 


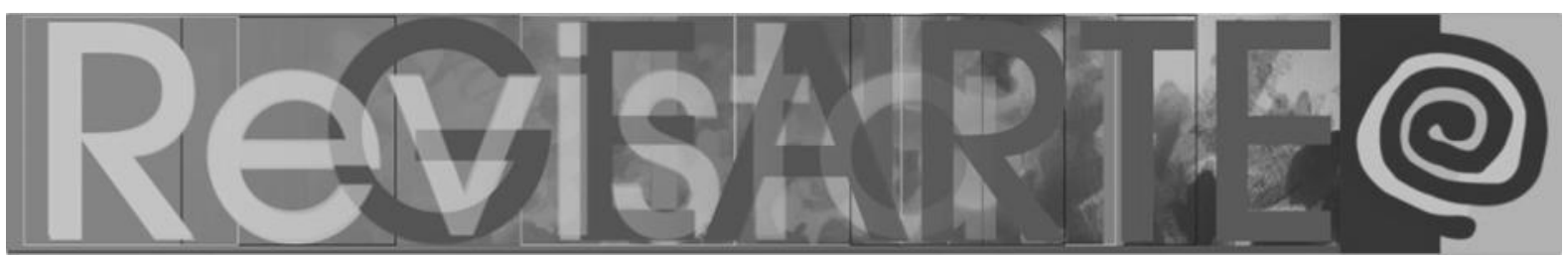

apresentam, mas que o professor dá uma nota ao trabalho de arte, uma coisa muito simbólica, muito singela, muito simples... — dizia a coordenadora Violeta.

— Eles não veem com uma matéria de peso né? ...um foco maior né? Concordava a coordenadora Hortênsia. (Informação verbal) ${ }^{3}$

Ao denotarem os impasses relacionados à arte na escola, as coordenadoras reforçam a relação que parece haver entre o ensino de arte e os componentes curriculares ensino religioso e educação física:

- Eu gostaria muito que se priorizasse mais a questão do trabalho da arte... a religião... - estendia a conversa a coordenadora Violeta.

- São algumas disciplinas que realmente... - concordava a coordenadora Hortênsia.

- Educação física! A gente recebeu reclamação de professor que... teve professor que recusou dar nota, porque ele disse assim: "como eu vou dar nota se eu não trabalho educação física? Se eu não tenho propriedade de trabalhar educação física?"... E o professor tá com razão, não tá não? Tá sim! - expôs a coordenadora Violeta.

— [...] Tá na grade curricular... o professor vai trabalhar uma coisa que ele não tem... Ele tem que trabalhar, mas ele não tem a propriedade, porque eu posso trabalhar de uma maneira errada, e aí? Eu estou lidando com crianças e educação física não é correr... num é? Não é um brincar só! - dizia a coordenadora Hortênsia.

- Veja só! Assim com a gente vê na arte, que não é só vê e pintar flor, a casinha, a bola... (educação física) não é só jogar bola não! — considerou a coordenadora Violeta.

- Não! De jeito nenhum! [...] é, [artes, religião e educação física] são as três disciplinas que as pessoas não enfocam, né? Aí diz assim: "Não, eu coloco qualquer nota porque não tem peso nenhum". Então... Mas você deveria... - concordou a coordenadora Hortênsia. (Informação verbal) ${ }^{4}$

As coordenadoras pedagógicas possibilitam-nos refletir acerca não só das homogeneidades entre a arte, o ensino religioso e a educação física, mas também acerca do que lhes difere, de suas heterogeneidades, que parecem acentuar ainda mais a classificação e a redefinição dos componentes curriculares nos anos iniciais do Ensino Fundamental.

A abordagem da realidade, de forma exclusivamente imanente ou transcendente, parece ser, neste momento, a sustentação da diferenciação entre estes componentes curriculares. Conforme as coordenadoras pedagógicas indicam-nos, há que se considerar diferentes cuidados frente ao corpo e às 


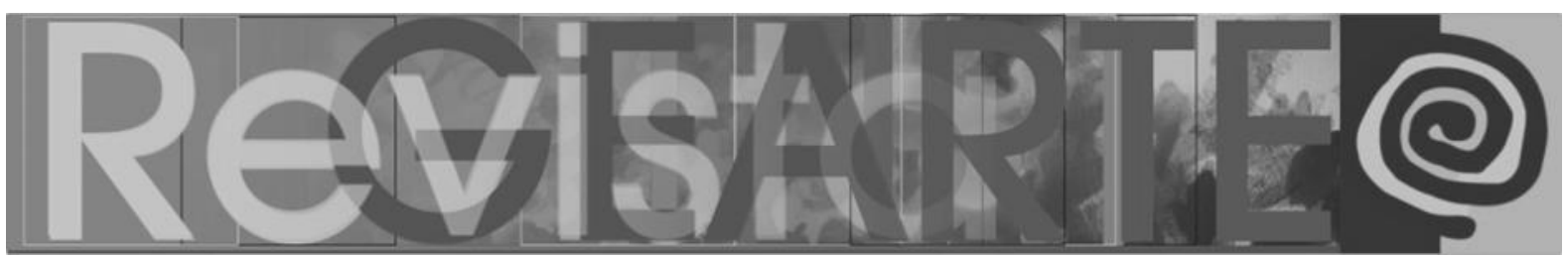

experiências, frente, por conseguinte, à arte, ao ensino religioso e à educação física:

— [...] A questão da arte, da arte não, da [educação] física, eu já fico pra traz, assim nessa questão, porque... - dizia a coordenadora Violeta.

- Tem que ter o cuidado, né? - Continuou a coordenadora Hortênsia.

- Tem que ter cuidado nisso aí, porque a criança... você pode fazer um movimento que não é correto e isso aí, eu mesma, vou no embalo do professor. Na sala de aula, eu vou fazer a mesma crítica que eles falam hoje né? Agora a questão da arte, da religião... não vejo não... restringia a coordenadora Violeta.

- E a não ser que o professor possua esse preparo né? Pra educação física, aí tudo bem! Mas, sem ter... é muito complicado! Aí vai ficar, realmente, só no jogar bola... pular corda e acabou! - concluiu a coordenadora Hortênsia. (Informação verbal) ${ }^{5}$

Paradoxalmente, o cuidado com o corpo e suas experiências é priorizado diante do cuidado com (o corpo e) as demais experiências das crianças, neste caso, a estética e a espiritual. Um possível dano no corpo físico parece maior que outros possíveis danos ou, ao menos, mais evidente. O corpo e a mente, o fazer e o pensar, o agir e o sentir parecem permanecer (desde a modernidade) incomunicáveis, inconciliáveis.

Neste sentido, inferimos que, talvez, advenha daí a ilegítima possibilidade de mobilizar apenas uma destas dimensões, de pensar em posicionar-se de um lado ou de outro, de ter que escolher entre os lados de menor ou maior peso, de privilegiar, de modo evidente, um destes lados na escola, a saber:

- Português! - disse a Flor, prontamente.

- Português, ciências, matemática, história... - dispararam sem parar a Raiz, o Gelo e a Onça Pintada.

- Português, matemática... - listaram o Papagaio, o Cavalo e o Macaco-Aranha, com os quais as flores concordaram.

- A exigência maior são os pesos: português e matemática. - Afirmou a professora Jasmim.

- Exatamente! Torna-se que você, querendo ou não, deixa um pouquinho de lado... o de arte porque requer... toma-se muito tempo na aula de arte [...] A exigência, o peso maior é língua portuguesa e matemática, então você vai trabalhar os descritores, vai trabalhar isso, trabalhar aquilo, então se fica a desejar geografia, história, ciências, artes e quanto mais como a arte, religião e educação física... fica mais ainda a desejar... - inferiu a professora Rosa Amarela.

- Deixa a desejar... - lamentou e concordou a professora Jasmim. (Informação verbal) $^{6}$ 


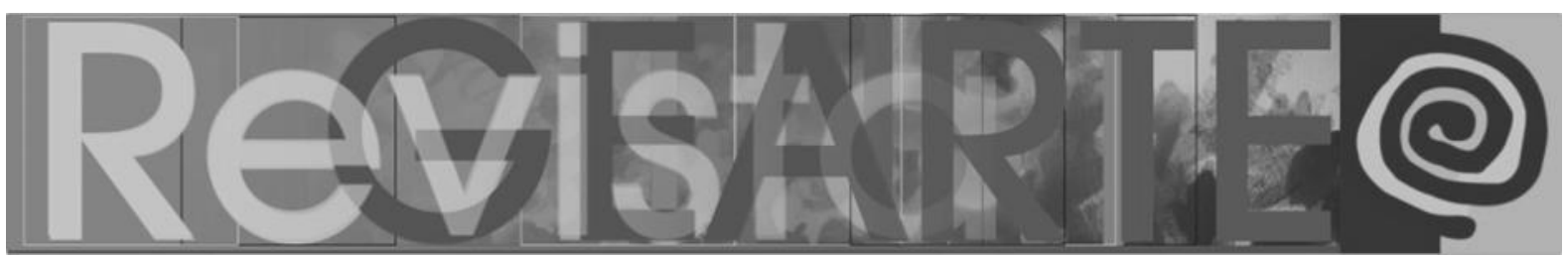

Tamanho peso, sobretudo da língua portuguesa e de matemática, parece imobilizar as crianças e as professoras, além das suas experiências na escola. Querendo ou não, conforme inferiu a professora Rosa Amarela, e lamentavelmente, conforme a professora Jasmim, os critérios de classificação e redefinição parecem permanecer e deixam a desejar - e o desejo parece ser ensinar e aprender para a vida e para o mundo, afinal "fazer um mundo melhor significava viver melhor; viver melhor pressupunha fazer um mundo melhor" (SKLIAR, 2019, p. 50).

Junto a este desafio que nos deixa a desejar junto às professoras, parece estar a relação com o tempo na escola. O modo como pensamos e vivenciamos o tempo é crucial à experiência, à educação, à pesquisa, à escrita, ao corpo, a nós - como já escrito no ponto anterior. Assim, mesmo antevendo os fios da arte escritos no próximo ponto, abordamos a relação com o tempo na escola, no ensino e na aprendizagem.

Juntamo-nos a Skliar (2019, p. 21) para refletir que:

A temporalidade é a experiência subjetiva do tempo e sabemos, desde os gregos, que essa experiência é diferente na infância, na juventude e na adultez. Desse choque entre intensidade, oportunidade e cronologia, deriva a maior parte dos labirintos pedagógicos.

Em meio a um desses labirintos pedagógicos, reconhecemos um desencontro possível na escola decorrente destas diferentes temporalidades.

Tal desencontro consiste no fato de que o desejo de aprender para a vida (de aprender, dentre outras coisas, a arte na escola) parece ser uma intensidade requerida pelas crianças, ao mesmo tempo que parece ser uma oportunidade identificada pelas professoras. No entanto, a cronologia parece ser um desafio para a efetivação desse desejo (enquanto oportunidade e intensidade), para o encontro entre o aprender, a vida e o mundo. 


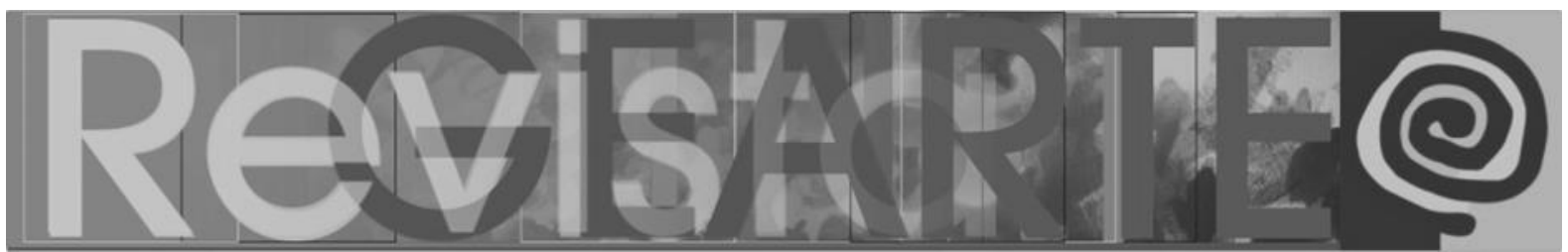

O tempo cronológico é citado pelas professoras, gestoras e coordenadoras quando conversamos acerca dos desafios da arte nos anos iniciais do Ensino Fundamental, do planejamento ao desenvolvimento de momentos para a arte na escola. Como elas destacam:

— [...] o tempo é pouco, mas a gente trabalha! — pontuou a coordenadora pedagógica Hortênsia.

- [...] e assim, a arte hoje ela tá sendo trabalhada, não como só antigamente, que achava que era só pintar, pintar, pintar, entendesse? Ela está hoje além dessa pintura! Num é? É fazer realmente a criança, ela criar, ela recriar... seu próprio pensamento, sua imaginação. - contava a coordenadora pedagógica Hortênsia.

- E também o fato de chegar na sala de aula na sexta-feira: aula de artes... na sexta-feira? É! Aula de arte! Aí o professor senta: "Pega o caderno de arte e desenha o que você quiser! Ai... isso me mata! [...] É pouco! Você tem que envolver o aluno pra que ele desenhe. Eu, na minha sala de aula, eu não gostava de levar assim, alguns momentos levei, reconheço que levei, mas eu não gostava, porque há dias realmente que a gente tá meio pra baixo, aí você sente que o professor senta na aula de arte! O professor senta! Desenhe o que vo... pegue o caderninho de arte e desenhe o que você quiser! Aí é diferente! [...] "Hoje nós vamos fazer um trabalho!" Ah eles trazem com força né?! Aquela folha tal e não sei o quê! E recorta aqui... tia eu não sei! Há um maior envolvimento do que quando é: tira o caderno de arte e desenha o que você quiser! Eles murcham! — disse a professora Rosa.

- A gente vê muito isso né? A falta disso, de ele trabalhar a arte desse jeito, de planejamento mais elaborado! [...] porque trazer o caderno mesmo, às vezes nem utiliza, depende muito do caderno de desenho que utiliza! Aí a gente vê, acho que essa "deficiência" entre aspas disso aí, trabalhar a arte nesse sentido! — considerou a professora Margarida. (Informação verbal) ${ }^{7}$

As professoras evidenciam a necessidade de um planejamento mais elaborado para a arte, atribuindo-a ao reconhecimento da arte e do seu ensino como processos de (re)criação, pensamento e imaginação, de um maior envolvimento com as crianças. E nesta insuficiência do tempo cronológico, as professoras demandam auxílio da secretaria de educação do município e de formação docente específica, conforme é possível identificar nas falas abaixo:

- Eu acho que, como eu falei, que as pessoas aqui da secretaria do município, os cargos mais... deveriam pensar, pra se colocar um... já que a BNCC não está sendo ainda desenvolvida, está ainda nessa fase de análise, de estudo... na questão da arte, mas que veja essa arte... reconheceu a coordenadora Hortência.

- [...] Eu acho que se fazia necessário um professor de educação física... mesmo que esse professor de educação física fosse pra arte que dá quase... se você souber conciliar... - considerava a professora Rosa Amarela. 


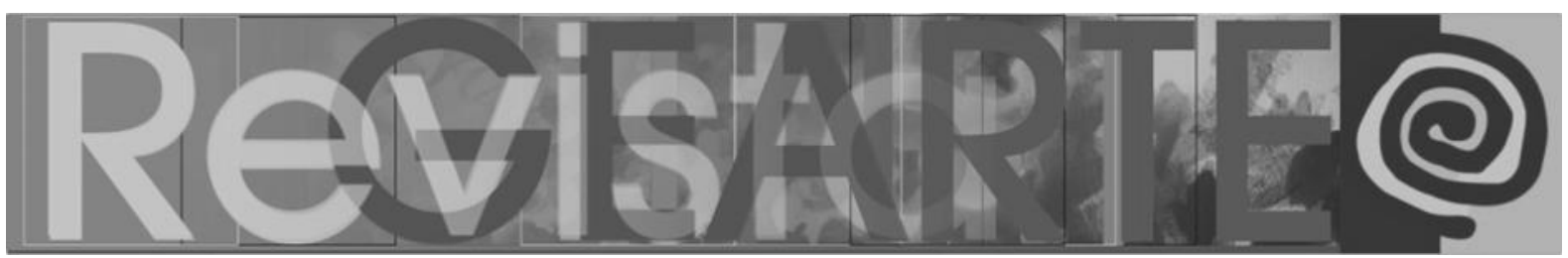

- Exatamente! ...Daria pelo menos essas duas, que fosse peso de outra pessoa... aí nossas aulas seriam também mais chatas, porque, querendo ou não, o conteúdo... - (re)considerou a professora Jasmim. (Informação ${\text { verbal })^{8}}^{2}$

As professoras, muito embora busquem soluções para os desafios da arte na presença de outros profissionais, destacam a importância de dar passagem à experiência em suas aulas, reconhecendo que a arte necessita escapar do pouco espaçotempo escolar reservado a ela, dando importância à arte e tecendo-a enquanto dispositivo potente de con-vivências em suas aulas. Sendo assim, a seguir, passam-nos às con-vivências tecidas pela arte nos anos iniciais do Ensino Fundamental, aos seus fios da arte tecidos pelas professoras em comunhão às crianças nas salas de aula.

\section{A artesania como fio de passagem da arte na escola}

As dicotomias (re)criadas na escola, a pressa e a escassez da temporalidade cronológica pouco têm a ver com a potencialização da aprendizagem, da vida e do mundo, pouco admitem espaçostempos para a arte nos anos iniciais do Ensino Fundamental. No entanto, entre tantos desafios, os corpos das professoras e das crianças tecem fios da arte na escola, fios de resistência emaranhados à experiência e à infância.

Assim, mesmo em meio aos desafios, partilhamos os fios da arte na escola. Algo nos aconteceu na educação, vivenciamos a experiência na escola junto às professoras e, sobretudo às crianças, quando partilhamos, por exemplo:

\footnotetext{
- A maquete! - anunciou o Gato Galáctico.

- Maqueteeee... foi a melhor coisa que eu já fiz! — contou cantando o Cachorro.

- O que eu mais gosto é que a gente fez a maquete. Eu queria fazer uma maquete bem grande! Foi legal. — contou o Sabiá.

- Foi! Pra fazer a casa do Papai Noel. - confirmou o Gato Marinheiro.

- Sim! O dia que eu mais gostei foi o dia que a gente fez a maquete! — disse a Fênix.

E a Coruja confirmou, contando que aprendeu a trabalhar em equipe, em dupla!
} 


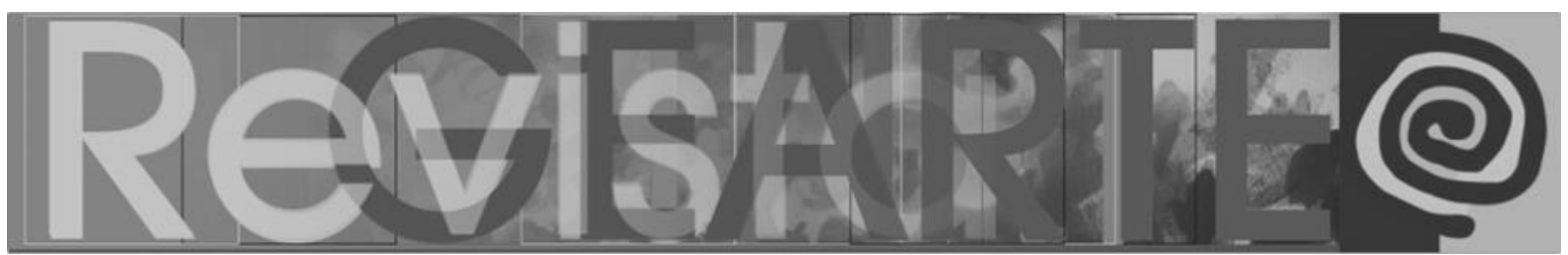

Dos momentos mencionados pelas crianças, destacamos os relacionados às maquetes. Neste ponto, tratamos seus modos de existência sob o ponto de vista das crianças, percebendo-os e dando-Ihes importância.

As crianças destacaram que estes ocorreram duas vezes durante o ano letivo da turma do terceiro ano A: uma durante as festividades de São João e outra durante as festividades do Natal. No primeiro momento, o Mar e o Gato Galáctico fizeram as melhores maquetes de festas de São João, segundo o Lobo Alfa, e todo mundo tirou dez, conforme comunicou o Sabiá. No segundo momento, as maquetes foram da casa do Papai Noel.

Nós estivemos presentes apenas no segundo momento. Tal proposta foi lançada pela professora Jasmim em uma sexta-feira: projetar a casa do Papai Noel e, em uma próxima sexta-feira, construir a maquete da casa. A professora entregou uma folha em branco para cada criança, inclusive para nós, e:

A essa altura, estávamos sentados em trio junto ao Jacaré, Urso Polar e ao Bulbassauro, imaginando como fazer o chão da nossa casa.

- Faz uns quadrados coloridos tia! —disse o Jacaré/Urso Polar.

- Boa ideia, podemos fazer um chão de almofadas! - dissemos.

O Bulbassauro também gostou da ideia e fez dela uma aventura:

- Eu vou fazer na minha também. Eita! Não dá porque a porta tá fechada. Porque tem um ladrão que quer roubar a casa. Mas tem uma fechadura. Mas o ladrão não vai abrir porque a chave é secreta, é uma senha: é ho ho ho. E o ladrão não sabe! - contava o Bulbassauro.

O Mar ouviu a chave secreta e quis contar ao Gato Galáctico e ao Sabiá, mas o Bulbassauro disse que já havia mudado. Depois avisou que não havia mudado, que era só para despistar...

O Sabiá irritou-se e disse:

- Pra que uma senha se [a casa do Papai Noel] é aberta?

- A do Bulbassauro é fechada! - dissemos ao Sabiá, que, surpreso, levantou-se de sua cadeira e veio até a mesa do Bulbassauro, dizendo:

- Cadê? Eu vou ver mesmo!

No encontro entre o Bulbassauro, o Sabiá, o Mar, o Gato Galáctico e o Jacaré, Urso Polar, a senha da casa de Papai Noel era sempre reconfigurada, enquanto, em outros encontros pela sala de aula, os projetos iam sendo finalizados: uns pisca-piscas aqui, umas portas de arrasto ali, umas chaminés cá, um pouco de neve lá... intervalo e ...um tal de ploc [um pulo para frente], Po-ploc ploc ploc [quatro pulos para trás], Po-ploc ploc ploc [quatro pulos para direita], Plo-ploc ploc ploc [quatro pulos para esquerda]... (Informação verbal $)^{9}$ 


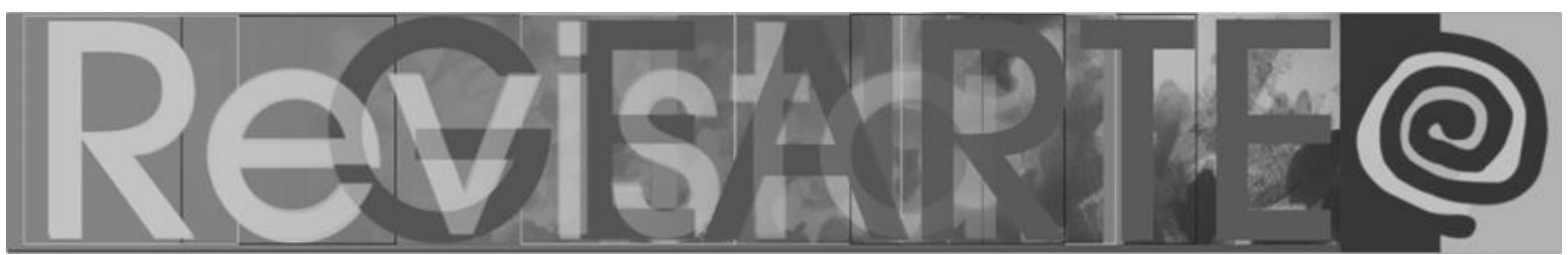

As crianças instauraram experiências estéticas neste momento, fizeram dele um tempo de intensidade, "que só é possível viver na convocação da presença feiticeira do outro" (GALLO; RODRIGUES, 2018, p. 219). Gallo e Rodrigues (2018) compreendem e problematizam outros modos de ser criança, atentando (e fazendo-nos atentar) a tempos de intensidade, como o descrito acima, quando há imaginação; aventura; riscos; imprevistos, como uma porta fechada; segredos; blefes; disponibilidade e abertura ao outro - sujeito da experiência (LARROSA BONDÍA, 2016); constante novidade; euforia por fim...

Este momento foi posto em destaque durante nossas conversas com as crianças, no entanto, Gallo e Rodrigues ratificam tempos de intensidade na escola ao considerarem que:

Todos os dias, nas relações que estabelecemos com os sujeitos da educação, como professo-aluno, aluno-aluno, aluno-professor, a presença do outro e de seu mundo, a nossa presença como outro e de nosso mundo, co-presenças com o mundo, nos permitem belas oportunidades de (des)aprendizagens. (GALLO; RODRIGUES, 2018, p. 218)

Assim, embora o espaçotempo escolar seja, muitas vezes, traduzido na imposição de limites à infância, ele impõe-nos, cotidianamente, a vida, as novidades do mundo - sendo a arte e seu ensino uma brecha para isso.

A seguir, imagens destas brechas e seus acessos.

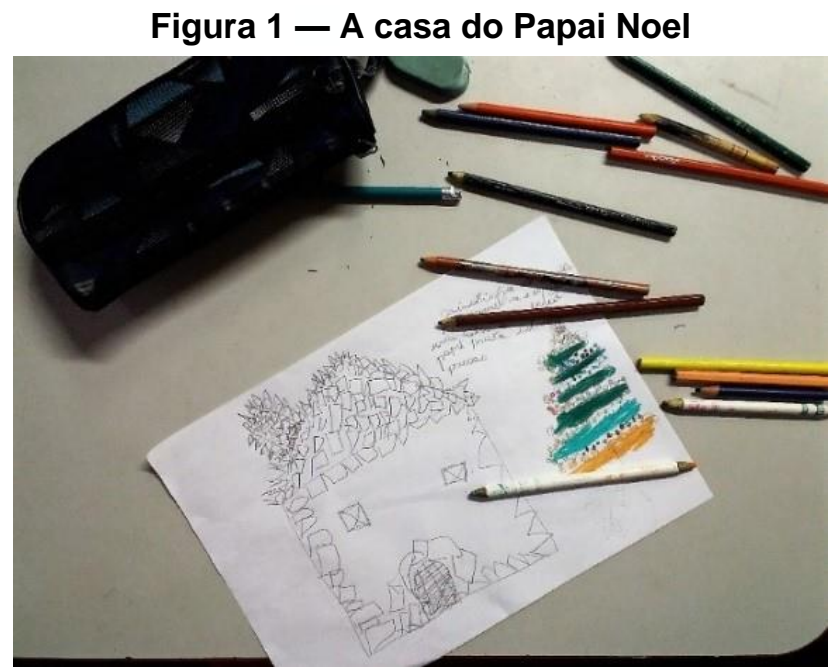

Fonte: Arquivo de Fernanda Albuquerque.

ALBUQUERQUE, Fernanda Maria Santos; SALLES, Conceição Gislâne Nóbrega Lima de; CARVALHO, Nádia 109 Priscila de Lima. Arte(sania) na escola: (desa)fios da arte nos anos iniciais do Ensino Fundamental. Revista GEARTE, Porto Alegre, v. 8, n. 1, p. 93-117, jan./abr. 2021.

Disponível em: http://seer.ufrgs.br/gearte 


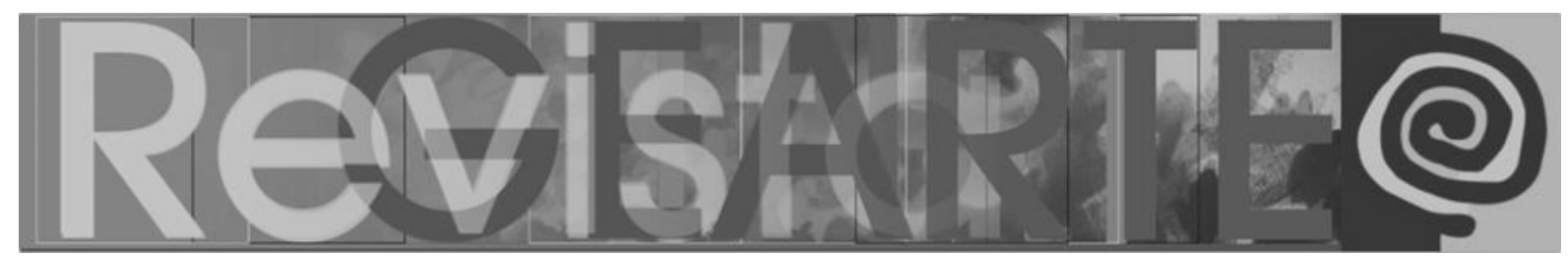

Figura 2 - Um tal de Ploc plo-ploc ploc ploc...

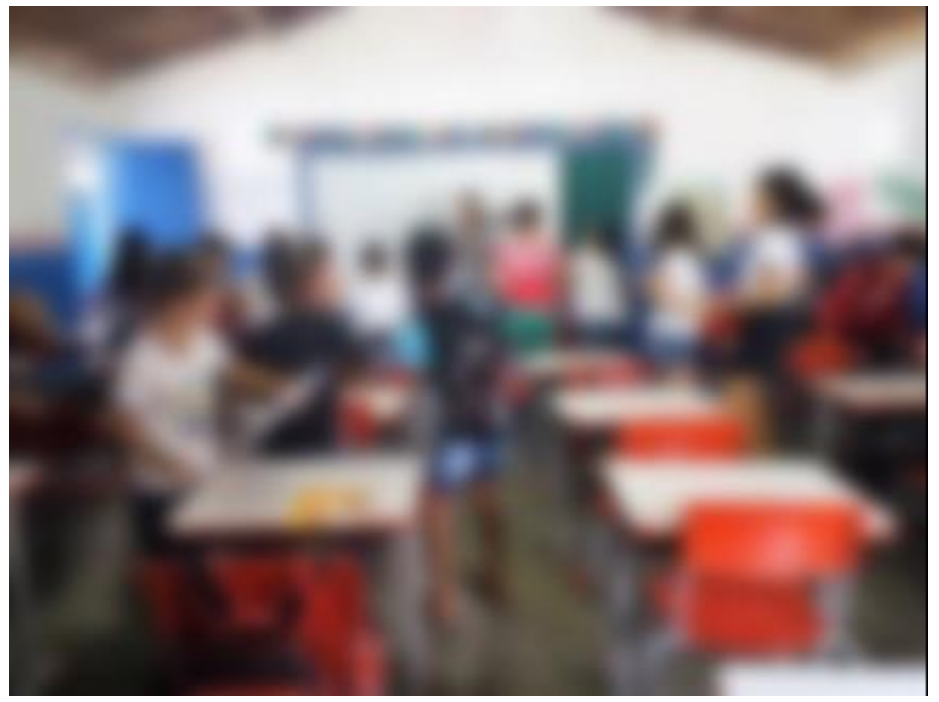

Fonte: Arquivo de Fernanda Albuquerque.

Estas brechas fazem-nos acessar deslocamentos outros. Os lápis de cor saíram do estojo, as crianças saíram de seus lugares, a pesquisa saiu de si, saímos de nós. As imagens falam-nos que nada permanece, que o aprendizado, a vida e o mundo são movidos pela arte, pela experiência e pela infância na escola. Elas dizem-nos o que já disseram Menezes e A-mi:

No mundo contemporâneo, ou por vezes denominado pós-moderno, a história do corpo vai ganhando novos tons, afinal, a vida tem potência infinita de variação e a história do corpo é a história de uma crise instaurada, um abalo sísmico que circula das entranhas da cultura à superfície da pele. (MENEZES; A-MI, 2017, p. 131)

Menezes e A-mi (2017) compreendem o corpo enquanto corporeidade que possibilita prolongamentos de si enquanto sujeito e objeto do ato artístico, o corpo cena-em-si que utiliza, no ensino e na vivência das artes, múltiplas formas de existência. As autoras mostram algumas possibilidades que corroboramos com as falas e as imagens das crianças apresentadas aqui. Seguem mais imagens, mais brechas, mais acessos: 


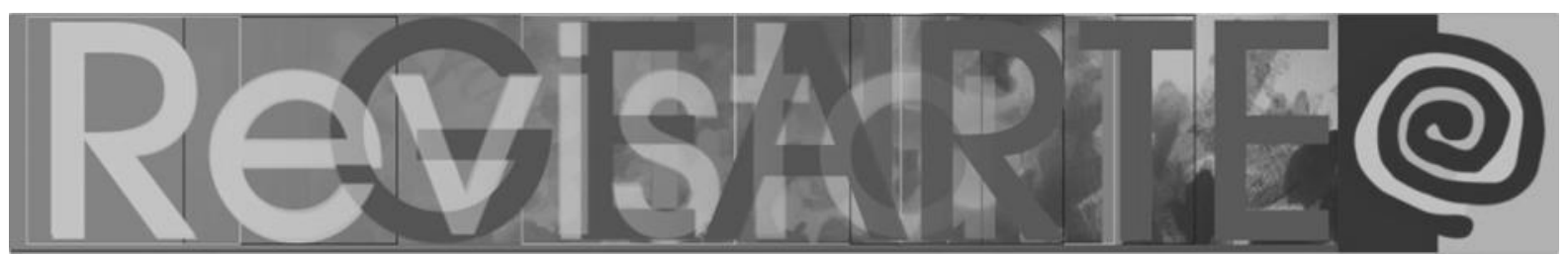

Figura 3 - Construção da casa do Papai Noel

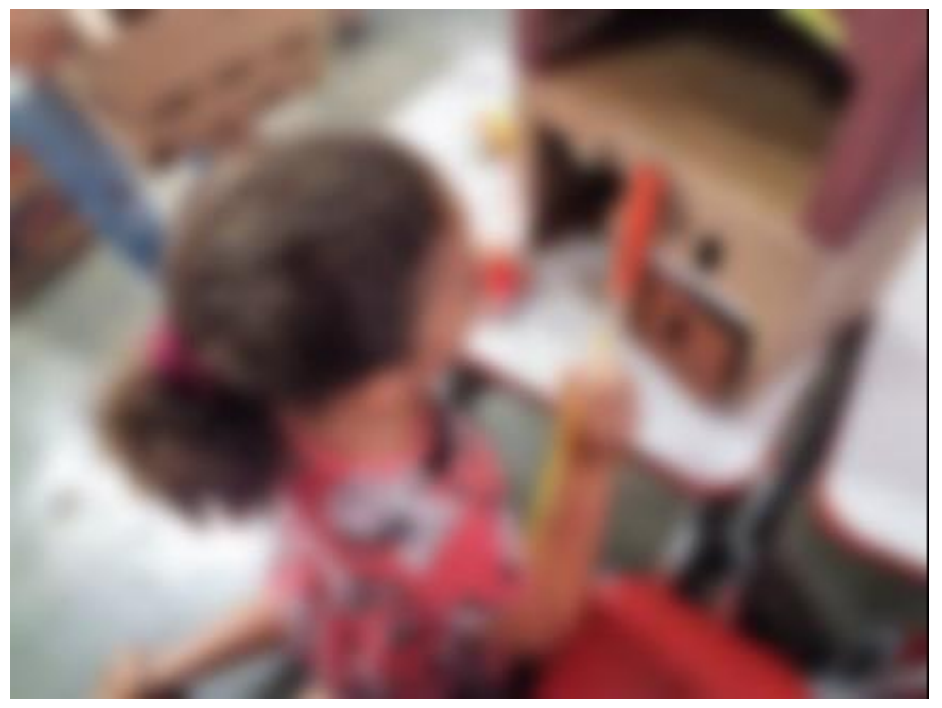

Fonte: Arquivo de Fernanda Albuquerque.

Figura 4 - Exibição da casa do Papai Noel

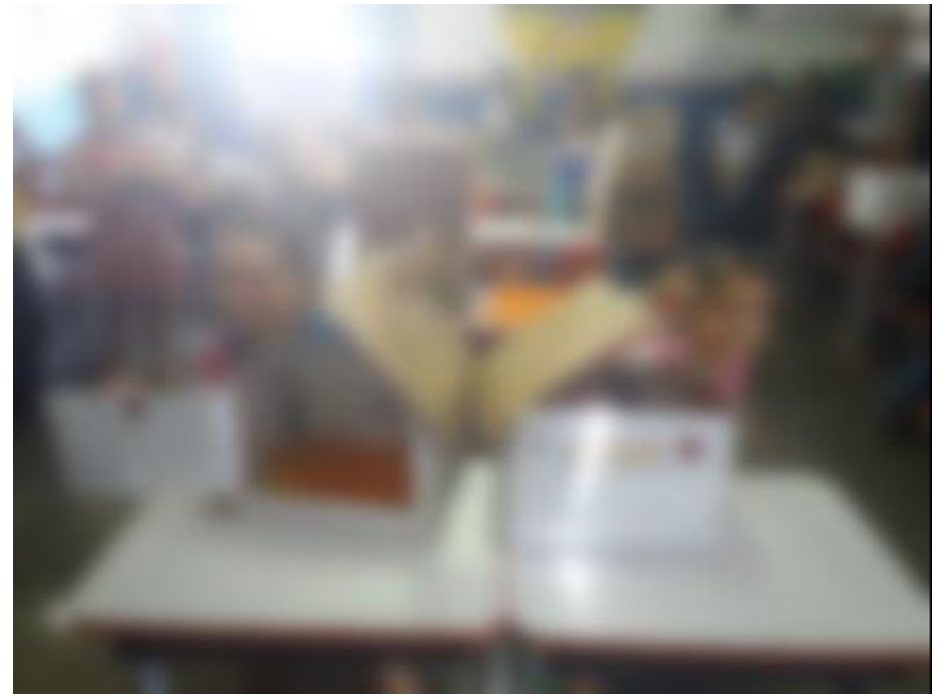

Fonte: Arquivo de Fernanda Albuquerque.

Estas imagens referem-se à sexta-feira indicada, quando as crianças construíram as casas projetadas. Houve construção de casas, mas também (des)construções, (des)aprendizagens, (des)confiança. Houve criatividade, solidariedade, ociosidade, conflitos, desafios, coletividades... durante toda a manhã. Poderíamos dizer que a intensidade do momento, do tempo aión, transbordou sobre o tempo chrónos que cedeu. Cedeu aos vários encontros, à multiplicidade destes; à demora diante dos mínimos detalhes da(s) obra(s); à 


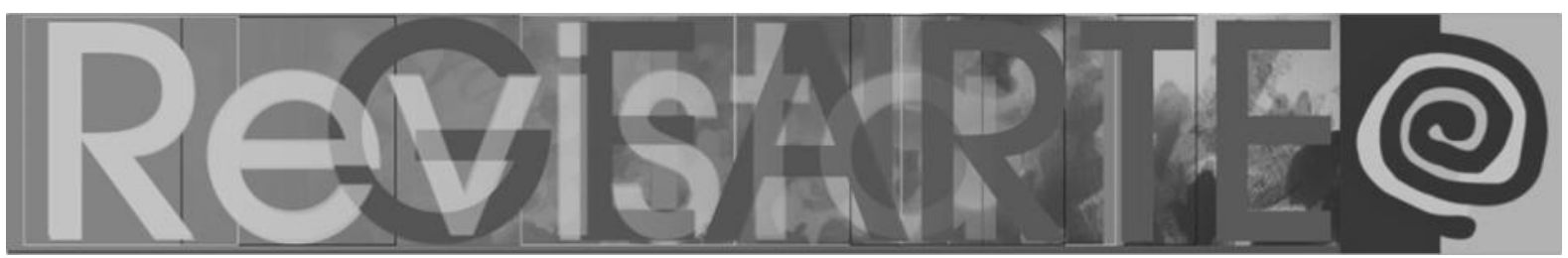

intensidade do ver e sentir, também do que imaginar; ao desejo de mostrar-se, de fazer-se saber presente.

Nestes momentos destacados pelas crianças vislumbramos a artesania, proposta de Sennett (2015a), como possibilidade de encontro e cooperação, de estar junto, e de habitar de modo intenso, com todo o corpo, o espaçotempo presente, neste caso, a escola. A proposta de Sennett de artesania e cooperação, junto à dialogia, já fora transposta para pensar as ações na área da educação, por exemplo, por Gobbato e Barbosa (2019), quando refletem acerca da formação de professores e das práticas docentes cotidianas, junto com as crianças.

Gobbato e Barbosa (2019) apontam essa possibilidade no contexto da educação infantil, ao que estendemos ao contexto dos anos iniciais do Ensino Fundamental. Consideramos que docentes tanto da Educação quanto dos anos iniciais do Ensino Fundamental junto às crianças

[...] poderiam, como movimento de resistência [a esse contexto destruidor da experiência nas sociedades contemporâneas], assumir o seu trabalho como artesanal e estabelecer didáticas não burocráticas em práticas relacionais. (GOBBATO; BARBOSA, 2019, p. 354)

Na escola, é possível tecer um fio de arte(sania), de con-vivência artesanal (SENNETT, 2015a). Nos momentos destacados acima, as crianças exploraram e instauraram os espaçostempos de planejamento e construção da maquete da casa do Papai Noel. Através da arte e do seu ensino, elas abriram brechas na escola, dando acesso e passagem "para aprender a cooperar e para constituir identidades múltiplas no interior de um processo ativo e múltiplo" - possibilidade exposta por Gobbato e Barbosa (2019, p. 363).

A escola, em todos os seus níveis e etapas, pode ser espaçotempo para aprender a viver e viver juntos, em um mundo, insistimos. Partimos dessa compreensão para dar importância aos acontecimentos e aos encontros que eventualmente podem surgir dessa relação específica com o outro, bem como 


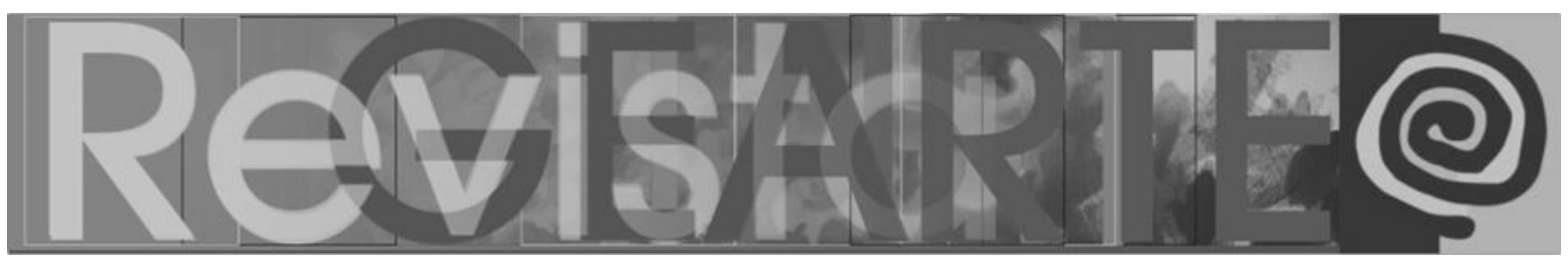

damos importância ao estabelecimento de estratégias na ação pedagógica planejada para evitar o cerceamento de sua emergência (PAGNI, 2014).

A partir do planejamento pedagógico da professora Jasmim, que parece terse valido de uma temporalidade de intensidade e oportunidade, as crianças tiveram a possibilidade de ocupar-se com o presente, ocupar-se com a própria vida. Ambas, crianças e professoras, assumiram uma atitude ética na educação escolar que possibilita novos estilos de existência, de corpo inteiro, da arte de viver.

Tal como aborda Pagni, acreditamos que:

[...] a arte de viver, por mais que faça parte de uma tradição abandonada, pode ser oportuna no presente, para se evidenciar a sua imiscuição advertida ou inadvertidamente nos dispositivos disciplinares e normativos da escola, assim como no tempo massificado e no controle contemporâneo que a pressionam, resistindo a eles e, quem sabe, transformando-os (PAGNI, 2014, p. 206).

Corroboramos Pagni (2014), ao refletir que, para além de uma preparação das crianças para se portarem em sociedade, é necessário considerar as atitudes diante da vida, a formação e o cultivo de si mesmo, a infância do próprio pensar. Junto às professoras e às crianças, vislumbramos as possibilidades da arte, a importância da experiência e a potência da infância na escola. Juntas, vislumbramos uma educação de possibilidades outras, de con-vivência artesanal, de uma intensidade temporal que transborde corpos, palavras, pensamento...

\section{Questões finais}

É possível ter mais arte na escola? É possível ter arte na escola? É possível escola? Desta vez evocamos as palavras e os gestos das crianças participantes da pesquisa, quando nos falavam do tanto de arte que há na escola. Mesmo tendo encontrado possíveis espaçostempos da arte (de viver) na escola, as crianças não deixam de denunciar a insuficiência destes. 


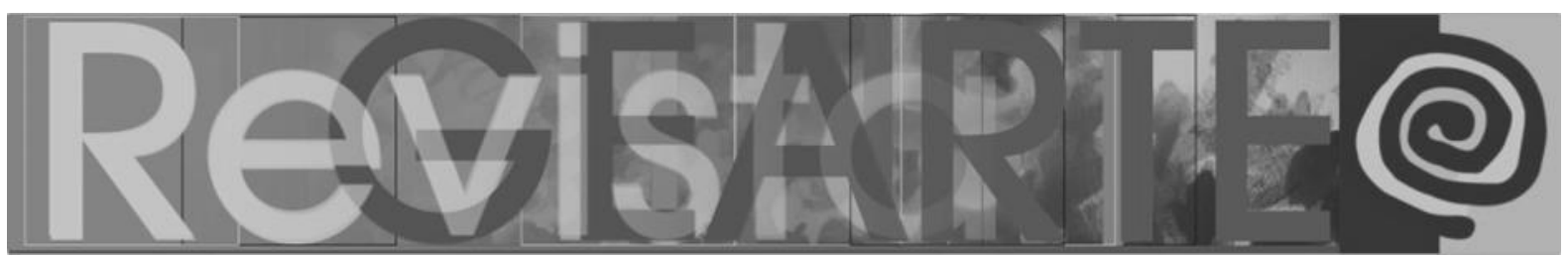

A Sereia, por exemplo, mostrou-nos seu dedo indicador e polegar aproximados, demonstrando o pouco de arte na escola. Quando perguntamos se poderia haver mais arte na escola, o Tarzan, o Urso, a Serpente e o Passarinho gritaram que "siiiiiiiiiiiiiiiiiiiim!" e a Sereia enfatizou: "É claro!”. E, ainda incomodada, a Sereia acrescentou que, para ter mais arte na escola, seria necessário implorar de joelhos:

— Pra todo mundo, até à diretora, à coordenadora, até pra você! — disse e acusou-nos com o seu dedo indicador. E continuou:

- Até para o prefeito...Botar algumas plaquinhas, umas bem grande do tamanho da escola, e escrever: bote arte em todas as escolas, até no Japão.

- Bote arte... muitos parques pra nós brincar! - acompanhou o Passarinho.

- Assim: a gente pegar uma placa bem grande pra escrever: artes para todas as crianças, até para o Japão. — reforçou a própria Sereia.

A intensidade com a qual as crianças colocam-nos a necessidade e a possibilidade de mais arte (de viver) na escola. Não basta falar (mesmo mais alto, mais de uma vez e com receptores bem definidos), é preciso dizer com o corpo, com toda sua indignação, mais de uma vez e de modos diferentes, o que já parece evidente...

A escola é sim espaçotempo de encontro entre crianças, professoras e pesquisadoras, entre arte, experiência e infância, entre aprendizagem, vida e mundo, entre corpos e escrita.

\section{Notas}

1 Fala da gestora Rosa em conversa durante a realização da pesquisa, Sairé, em 11 dez. 2018.

2 Fala da coordenadora pedagógica Violeta em conversa durante a realização da pesquisa, Sairé, em 23 dez. 2018.

3 Falas das coordenadoras pedagógicas Violeta e Hortênsia em conversa durante a realização da pesquisa, Sairé, em 23 dez. 2018.

4 Falas das coordenadoras pedagógicas Violeta e Hortênsia em conversa durante a realização da pesquisa, Sairé, em 23 dez. 2018.

5 Falas das coordenadoras pedagógicas Violeta e Hortênsia em conversa durante a realização da pesquisa, Sairé, em 23 dez. 2018. 


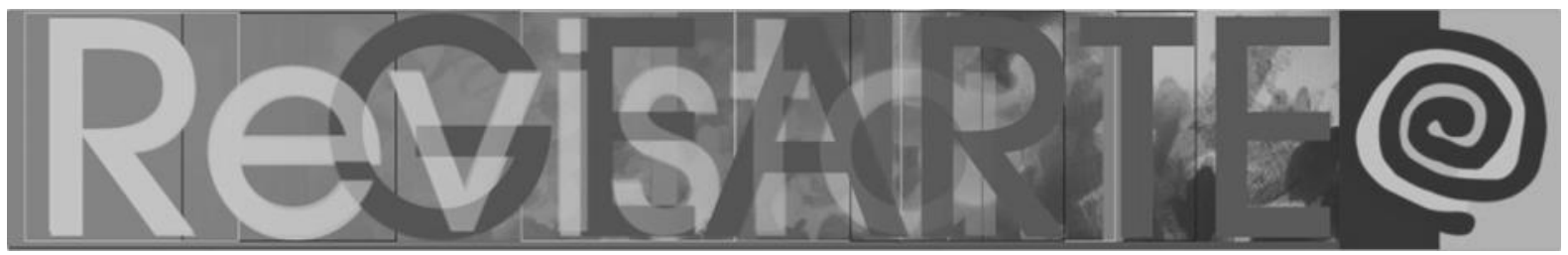

6 Falas das crianças e das professoras Jasmim e Rosa Amarela em conversas durante a realização da pesquisa, Sairé, em 12 dez. 2018.

7 Falas da coordenadora pedagógica Hortênsia e das gestoras Rosa e Margarida em conversas durante a realização da pesquisa, Sairé, em 11 e 23 dez. 2018.

8 Falas da coordenadora pedagógica Hortênsia e das professoras Rosa Amarela e Jasmim em conversas durante a realização da pesquisa, Sairé, em 23 e 12 dez. 2018.

9 Falas das crianças em conversa durante a realização da pesquisa, Sairé, em 16 nov. 2018.

\section{Referências}

BARROS, Manoel de. Meu quintal é maior do que o mundo. Rio de Janeiro: Objetiva, 2015.

BENJAMIN, Walter. Magia e técnica, arte e política: ensaios sobre literatura e história da cultura. São Paulo: Brasiliense, 1987.

DUARTE JÚNIOR, João-Francisco. O sentido dos sentidos: a educação (do) sensível. 2000. 233 f. Tese (Doutorado em Educação) - Faculdade de Educação, Universidade Estadual de Campinas, Campinas, 2000. Disponível em: http://www.repositorio.unicamp.br/handle/REPOSIP/253464. Acesso em: 26 jul. 2018.

FERRAÇO, Carlos Eduardo; ALVES, Nilda. Conversas em redes e pesquisas com os cotidianos. In: RIBEIRO, Tiago; SOUZA, Rafael de; SAMPAIO, Carmen Sanches (org.). Conversas como metodologia de pesquisa: por que não? Rio de Janeiro: Ayvu, 2018. p. 41-65.

GALLO, Sílvio; RODRIGUES, Alexsandro. Sexualidades e infâncias: (des)viar conversas que afirmam uma infância, para fiar preocupações com a novidade da criança em aparecimentos. In: RODRIGUES, Allan de Carvalho; BERLE, Simone; KOHAN, Walter Omar (org.). Filosofia e educação em errância: inventar escola, infâncias do pensar. Rio de Janeiro: NEFI, 2018. p. 213230.

GOBBATO, Carolina. BARBOSA, Maria Carmen Silveira. A artesania, o diálogo e a cooperação: uma perspectiva para a didática na educação infantil. POIÉSIS, Tubarão, v. 13, n. 24, p. 350-365, 2019. Disponível em: http://portaldeperiodicos.unisul.br/index.php/Poiesis/article/view/8254. Acesso em: 19 maio 2020.

KOHAN, Walter Omar. Infância, estrangeiridade e ignorância: ensaios de filosofia e educação. Belo Horizonte: Autêntica, 2007.

LARROSA BONDÍA, Jorge. Notas sobre a experiência e o saber de experiência. Revista Brasileira de Educação, Rio de Janeiro, n. 19, p. 20-28, 2002. Disponível em: http://www.scielo.br/pdf/ rbedu/n19/n19a02.pdf. Acesso em: 13 dez. 2016.

LARROSA BONDÍA, Jorge. Experiência e alteridade em educação. Reflexão e Ação, Santa Cruz do Sul, v. 19, n. 2, p. 4-27, 2011. Disponível em: https://online.unisc.br/seer/index.php/reflex/ article/view/2444/1898. Acesso em: 5 dez. 2016.

LARROSA BONDÍA, Jorge. Tremores: escritos sobre experiência. Tradução Cristina Antunes, João Wanderley Geraldi. Belo Horizonte: Autêntica, 2016.

MENEZES, Rosália. A-MI, Jo. Corpo que paira, corpo que flui: corporeidades múltiplas na artevivência. Revista GEARTE, Porto Alegre, v. 4, n. 1, p. 127-140, 2017. Disponível em: http://seer.ufrgs.br/gearte/article/view/70906. Acesso em: 27 maio 2020.

OLARIETA, Beatriz Fabiana. O sol e as laranjas: ou sobre o lugar onde as crianças e a poesia se encontram. Childhood \& Philosophy, Rio de Janeiro, v. 9, n. 17, p. 11-23, 2013.

ALBUQUERQUE, Fernanda Maria Santos; SALLES, Conceição Gislâne Nóbrega Lima de; CARVALHO, Nádia 115

Priscila de Lima. Arte(sania) na escola: (desa)fios da arte nos anos iniciais do Ensino Fundamental.

Revista GEARTE, Porto Alegre, v. 8, n. 1, p. 93-117, jan./abr. 2021.

Disponível em: http://seer.ufrgs.br/gearte 


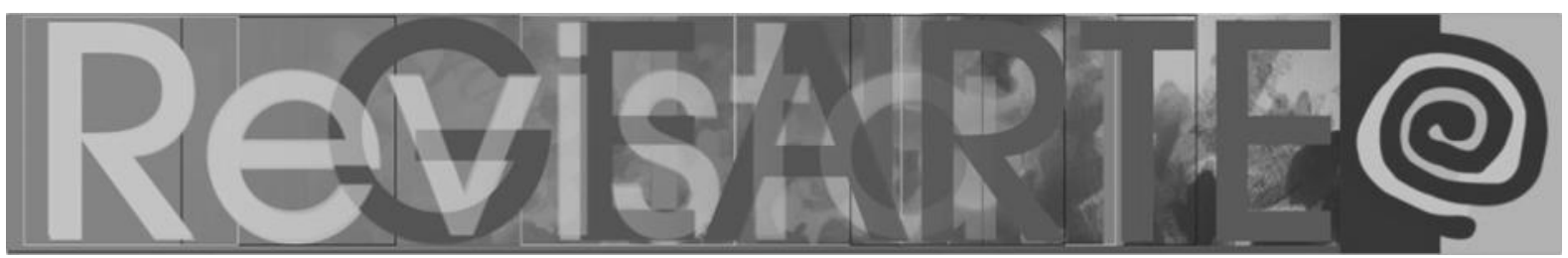

PAGNI, Pedro Angelo. Experiência estética, formação humana e arte de viver: desafios filosóficos à educação escolar. São Paulo: Loyola, 2014.

PASSOS, Eduardo; KASTRUP, Virgínia; ESCÓSSIA, Liliana (org.). Pistas do método da cartografia: pesquisa-intervenção e produção de subjetividade. Porto Alegre: Sulina, 2015.

RODRIGUES, Luiza Silva; ROBLE, Odilon José. Educação dos sentidos na contemporaneidade e suas implicações pedagógicas. Pro-Posições, Campinas, v. 26, n. 3, p. 205-224, 2015.

SABINO, Kelly C. Experiência: Uma arqueologia entre a arte e a educação. In: REUNIÃO ANUAL DA ANPED, 38., 2017, São Luís. Anais [...]. São Luís: Anped, 2017. Disponível em: http://anais.anped.org.br/sites/default/files/arquivos/trabalho_38anped_2017_GT24_203.pdf.

Acesso em: 20 jan. 2018.

SENNETT, Richard. A cultura do no capitalismo. Tradução Clóvis Marques. Rio de Janeiro: Record, 2006.

SENNETT, Richard. O artífice. Tradução Clóvis Marques. 5. ed. Rio de Janeiro: Record, 2015a.

SENNETT, Richard. Juntos: os rituais, os prazeres e a política da cooperação. Tradução Clóvis Marques. 3. ed. Rio de Janeiro: Record, 2015b.

SKLIAR, Carlos. A escuta das diferenças. Porto Alegre: Mediação, 2019.

STRAZZACAPPA, Márcia. A educação e a fábrica de corpos: a dança na escola. Cadernos Cedes, Campinas, v. 21, n. 53, p. 69-83, 2001. Disponível em: https://www.scielo.br/pdf/ccedes/v21n53/ a05v2153.pdf. Acesso em: 28 maio 2020.

\section{Fernanda Maria Santos Albuquerque}

Mestra em Educação Contemporânea pela Universidade Federal de Pernambuco. Graduada em pedagogia pela Universidade Federal de Pernambuco/Campus Acadêmico do Agreste. Membro do Grupo de Pesquisa Discursos e Práticas Educacionais. Professora dos anos iniciais do Ensino Fundamental no município de Toritama-PE.

ORCID: https://orcid.org/0000-0003-1852-9247

E-mail: fernanda.m.s.albuquerque@gmail.com

Currículo: http://lattes.cnpq.br/0373233130566792

\section{Conceição Gislâne Nóbrega Lima de Salles}

Graduada em Pedagogia pela Universidade Federal de Pernambuco, mestre e doutora (2008) em Educação pela Universidade Federal de Pernambuco. Atualmente é Professora Associada II do Centro Acadêmico do Agreste da Universidade Federal de Pernambuco, onde atua no curso de graduação em Pedagogia e docente permanente do programa de pós-graduação em Educação Contemporânea (PPGEduc).É coordenadora do programa de pós-graduação em Educação Contemporânea-PPGEDUC/Campus Agreste.

ORCID: https://orcid.org/0000-0003-3930-512X

E-mail: cgislane@terra.com.br

Currículo: http://lattes.cnpq.br/8110858923692305 


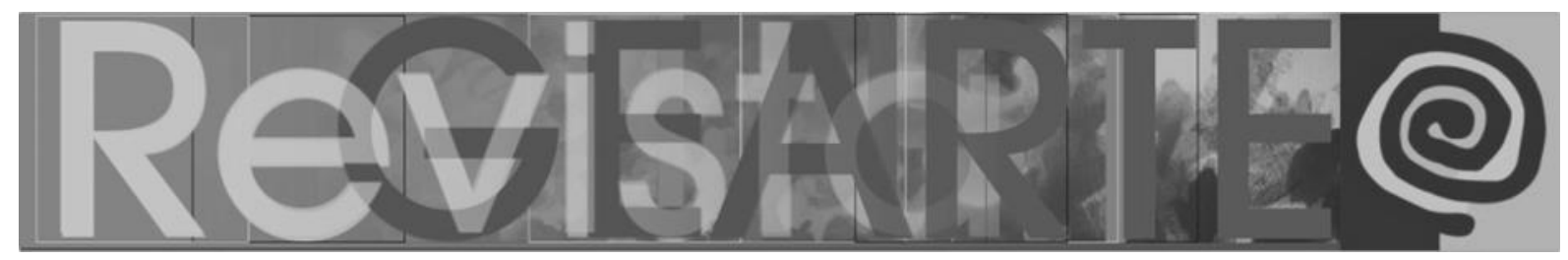

Nádia Priscila de Lima Carvalho

Mestre em Educação Contemporânea pela Universidade Federal de Pernambuco pelo Centro Acadêmico do Agreste em Caruaru. Participante do Grupo de Pesquisa: Discursos e Práticas Educacionais pela UPPE-CAA, Caruaru/PE.

ORCID: https://orcid.org/0000-0002-8088-5341

E-mail: nadiapri1@hotmail.com

Currículo: http://lattes.cnpq.br/0186950885797948

Recebido em 31 de maio de 2020 Aceito em 20 de outubro de 2020 